\title{
Pengaruh Model Discovery Learning Pada Mata Pelajaran IPA Terpadu Terhadap Penguasaan Literasi Sains Siswa
}

\author{
Uli Ulfa', Ernawati Saptaningrum ${ }^{2)}$, Affandi Faisal Kurniawan ${ }^{3)}$ \\ Pendidikan Fisika, FPMIPATI Universitas PGRI Semarang \\ Jl. Sidodadi Timur No. 24 Dr. Cipto Semarang 50125 Jawa Tengah \\ email: ulfauli38@gmail.com
}

\begin{abstract}
This research motivated by the result of evaluation student's ability in literacy science through test PISA more declined. Student's ability in literacy science influenced by learning model. Learning model reputed can increase student's ability in literacy science is model discovery learning, because discovery learning modified between invention and investigation problem, so it can increase student's comprehension of concept applied in daily activity. Purpose of this research is to know influenced model discovery learning at sience integrated to authority student's literacy science. Design of this research is nonequivalent control Group Design. Location of this research is SMP N I on 16-23 May 2016. Method to take data was used test and non-test method they are pretest and posttest, quesioner, and observation sheet. The Test used question of PISA 2009 and it has been translated into Indonesian language. Above to first stage of data analysis concerning result of prestest trough normalities dan homogeniety test showed that both of experiment and control class was normal and homogen. Result of students' ability to answer science questions of PISA at the fastest stage for experiment and control class have averaged 60 and 61, both of the sample classes have value of average which almost same. Above to last stage of data analysis through t-test showed that tcount $<$ ttable therefore Ho was received. The conclusion of this research is there is not influence of model discovery learning at science integrated to authority student's literacy science. Model discovery learning can't influenced to student's literacy science because at the first stage to introduce PISA question, students need teacher's intensive guidance, it's antipodes with model discovery learning which in applied of model discovery learning, students ask to learn by them self antonomously, therefore it will be effective if used model contextual learning at introduced stage of literacy science and PISA's question.
\end{abstract}

Keywords : Discovery Learning, Literacy Sains, PISA (Programme International Students Assesment)

Abstrak: Penelitian ini dilatar belakangi oleh hasil evaluasi kemampuan litersi sains siswa di
Indonesia melalui tes PISA semakin menurun. Kemampuan literasi sains siswa salah satunya
dipengaruhi oleh model pembelajaran. Model pembelajaran yang dianggap mampu meningkatkan
kemampuan literasi sains siswa adalah model discovery learning, karena model ini memodifikasi
antara penemuan dan penyelidikan dalam memecahkan masalah sehingga dapat meningkatkan
pemahaman konsep siswa yang dapat diterapkan di lapangan. Penelitian ini bertujuan untuk
mengetahui pengaruh model discovery learning pada mata pelajaran IPA Terpadu terhadap
penguasaan literasi sains siswa. Desain penelitian yang digunakan adalah Noneequivalent Control
Group Desain. Lokasi penelitian adalah SMP Negeri I Tayu pada tanggal 16 sampai 23 Mei 2016 .
Subjek penelitian adalah siswa dari kelas VII. Sampel terdiri dari dua kelas yang diambil degan teknik
cluster random sampling. Metode pengumpulan data menggunakan metode tes yaitu pretest dan
postest, angket, dan lembar observasi. Tes yang diberikan menggunakan soal-soal yang diperoleh dari
soal PISA 2009. Hasil kemampuan siswa dalam menjawab soal sains PISA pada tahap postest kelas
eksperimen dan kelas kontrol mempunyai rata-rata sebesar 60 dan 61 . Berdasarkan analisis tahap
akhir dengan menggunakan uji $\mathrm{t}$ menyatakan bahwa $\mathrm{t}_{\text {hitung }}<\mathrm{t}_{\text {tabel }}$ yaitu $\mathrm{t}_{0,281}<\mathrm{t}_{0,559}$ olehkarenaitu
$\mathrm{H}_{0}$ diterima. Dari hasil penelitian ini dapat disimpulkan bahwa tidak ada pengaruh model discovery 
learning pada mata pelajaran IPA Terpadu terhadap penguasaan literasi sains siswa. Model discovery learning tidak memberi pengaruh terhadap penguasan literasi sains siswa karena pada tahap pengenalan soal PISA siswa membutuhkan tuntunan dan bimbingan guru secara intensif, hal ini berlawanan dengan model discovery learning dimana dalam penggunaan model discovery learning ini siswa di tuntut untuk belajar mandiri untuk menemukan dan menyelidiki suatu masalah, oleh karena itu akan lebih efektif jika dugunakan model pembelajaran langssung pada tahap pengenalan soal-saoal terjemahan PISA.

Kata Kunci: Discovery learning, Literasi Sains, PISA (Programme International Study Assesment)

\section{PENDAHULUAN}

Indonesia telah menjadi partisipan PISA semenjak tahun 2000, namun hasil yang didapatkan masih kurang memuaskan. Hasil tes PISA pada tahun 2012 menunjukkan bahwa diantara 65 negara tersebut, Indonesia menduduki peringkat kedua dari bawah yaitu peringkat 64 dari 65 negara peserta dengan skor rata-rata Internasional.

Untuk meningkatkan kemampuan literasi sains di samping memerlukan motivasi berprestasi peserta didik, guru juga perlu membertimbangkan strategi pembelajaran yang terkait dengan model pembelajaran yang digunakan agar peserta didik dapat lebih mudahmencapai tujuan belajarnya.

Dari hasil penelitian yang dilakukan oleh (Ekohariadi, 2009) menyatakan bahwa korelasi literasi sains dengan penggunaan fenomena mengilustrasikan topik, problem based learning dan penyelidikan lab bernilai negatif, sedeangkan Project based learning memberikan kesempatan kepada perserta didik untuk menggali konten (materi) dengan menggunakan berbagai cara yang bermakna bagi dirinya, dan melakukan eksperimen secara kolaboratif atau penyelidikan lab, dari pernyataan tersebut menunjukkan bahwa model project based learning juga berkorelasi negatif terhadap literasi sains.

Model pembelajaran yang dipandang tepat dalam mengatasi situasi seperti ini serta sesuai dengan kurikulum 2013 adalah model pembelajaran discovery learning, karena dengan model pembelajaran ini memodifikasi antara penemuan dan penyelidikan yang akan menumbuhkan sikap kreatif dan kritis para peserta didik. Kegiatan belajar mengajar yang menggunakan metode penemuan (discovery) mirip dengan metode inkuiri (inquiry).

Secara tersirat penelitian yang dilakukan PISA terhadap peserta didik yang berusia 15 tahun menyatakan pentingnya mempersiapkan sumber daya manusia yang berkualitas sejak dini mulai dari sekolah dasar dan sekolah menengah. Oleh karena itu peneliti ingin mengangkat sebuah penelitian yang berjudul "Pengaruh Model Discovery Learning pada Mata Pelajaran IPA Terpadu terhadap Penguasaan Literasi Sains Siswa".

\section{METODE PENELITIAN}

Penelitian dilaksanakan di SMP Negeri 1 Tayu, Pati. Sasaran penelitiannya ditujukan kepada siswa berusia kurang dari 15 tahun atau setara dengan siswa-siswi kelas VII.

Desain eksperimen yang digunakan dalam penelitian ini adalah Quasi Experimental Design. Desain ini mempunyai kelompok kontrol, tetapi tidak berfungsi sepenuhnya untuk mengontrol variabel-variabel luar yang mempengaruhi pelaksanaan eksperimen. Sampel yang digunakan diambil secara random dari populasi tertentu (Sugiyono, 2011).

Dalam desain ini terdapat dua kelompok yang dipilih secara random, kemudian diberi prestest untuk mengetahui keadaan awal adakah perbedaan antara kelompok eksperimen dan kelompok kontrol. Hasil pretest yang baik bila nilai kelompok ekspeprimen tidak berbeda secara signifikan. 
Populasi dalam penelitian ini adalah seluruh siswa kelas VII semester geanap SMP N 1 Tayu Tahun Pelajaran 2015/2016. Sampel pada penelitian ini akan diambil dua kelas dari jumlah kelas VII dengan kelas pertama sebagai kelas eksperimen dan kelas kedua sebagai kelas 259riteri. Dalam penelitian ini sampel diambil mengunakan eknik cluster random sampling.

Variabel Bebas pada penelitian yang akan dilakukan ini adalah model discovery learning. Variabel terikat (Y) dalam penelitian yang akan dilaksanakan adalah kemampuan literasi sains siswa dilihat dari hasil belajar mata pelajaran IPA terpadu siswa SMP N 1 Tayu Tahun ajaran 2015/2016.

Metode pengumpulan data menggunakan metode tes yaitu pretest dan 259riteria, angket karakteristik literasi sains siswa, dan lembar observasi keterlakasanaan model discovery learning. Tes yang diberikan menggunakan soal-soal yang diperoleh dari soal PISA 2009 dan sudah diterjemahkan ke dalam Bahasa Indonesia.

Untuk menganalisa data yang telah diperoleh dari hasil penelitian peneliti menggunakan pendekatan kuantitatif, yaitu analisis yang mewujudkan data dalam bentuk angka. Data kuantitatif yang digunakan dalam penelitian berupa hasil tes soal-soal terjemahan PISA yang telah dikerjakan oleh siswa. Hasil jawaban siswa diperiksa dan diteliti secara manual satu persatu denga menggunakan kunci jawaban yang terdapat dalam Take the Test Take the Test: Sampel Question from OECD's PISA Assessment untuk menentukan jumlah soal benar. Pemberian skor dari soal-soal PISA terdiri dari tiga 259riteria penilaian, yaitu "full credit", "partial credit", dan "no credit". Skor penuh atau full credit adalah 2, skor ini diberikan untuk jawaban benar dan sempurna yang menunjukkan pemahaman ilmiah yang baik terhadap materi. Skor setengah benar atau partial credit adalah 1, skor ini diberikan untuk jawaban benar tetapi tidak sempurna, yang menunjukkan kurangnya pemahaman ilmiah terhadap materi yang dibahas. Jawaban siswa yang termasuk dalam kriteria "Partial Credit" memiliki kapasitas level yang lebih rendah dibandingkan dengan jawaban siswa yang termasuk dalam 259riteria "Full Credit". Jadi terdapat beberapa soal yang memiliki dua level berbeda yang tergantung dari hasil jawaban siswa. Tabel di bawah menyajikan daftar nomor soal dan level yang berbeda dari setiap kriteria "Full Credit"dan "Partial Credit".

Tabel 1. Daftar Nomor Soal Dan Level Kemampuan Siswa Untuk Kriteria Penilaian "Full Credit"

Dan "Partial Credit"

\begin{tabular}{cccc}
\hline & \multirow{2}{*}{ No. } & \multicolumn{2}{c}{ Level } \\
\cline { 3 - 4 } No. & Soal & $\begin{array}{c}\text { Full } \\
\text { Credit }\end{array}$ & $\begin{array}{c}\text { Partial } \\
\text { Credit }\end{array}$ \\
\hline 1. & 1.1 & 5 & 4 \\
\hline 2. & 2.2 & 6 & 5 \\
\hline 4. & 3.2 & 5 & 4 \\
\hline 5. & 5.3 & 6 & 3
\end{tabular}

Sementara untuk skor salah atau nol credit adalah nol, untuk jawaban salah atau jawaban yang tidak diisi sama sekali. Kemudian dihitung persentase rata-rata dari seluruh skor siswa, dengan menggunakan rumus:

Keterangan :

$$
\bar{x}=\frac{\sum x_{i}}{\sum n_{i}} \times 100 \%
$$

$\bar{x} \quad$ : Persentase rata-rata $(\%)$

$\Sigma \quad$ : Epsilon (baca jumlah)

$\mathrm{x}_{\mathrm{i}} \quad$ : Total Skor Siswa 
$\Sigma \mathrm{n}_{\mathrm{i}} \quad$ : Jumlah individu

Sedangkan untuk menghitung persentase kemampuan rata-rata siswa pada setiap level menggunakan rumus Purwanto (2009):

$$
\mathrm{Np}=\frac{R}{S} \times 100 \%
$$

Keterangan :

$\mathrm{Np}$ : Persentase skor yang diharapkan

$\mathrm{R} \quad$ : Skor rata-rata siswa per level

Sm : Skor maksimum ideal dari tes

Kemudian dilakukan penafsiran persentase kemampuan rata-rata siswa pada setiap level berdasarkan hasil perhitungan di atas. Data tersebut kemudian disajikan dalam bentuk uraian deskriptif dalam pembahasan. Dilakukan pula penafsiran kemampuan siswa dalam menjawab soal-soal terjemahan PISA. Penafsiran ini dilakukan untuk menentukan kategori yang sesuai dengan skala PISA(2009) sebagai berikut:

1. Rendah : Siswa pada kategori ini dinilai mampu untuk menjawab soal pada level 2 dan level 3. Bahkan siswa juga tidak mampu untuk menjawab soal pada level 1.

2. Sedang : Siswa pada kategori ini dinilai mampu untuk menjawab soal pada level 1 dan level 2, dan mungkin siswa juga mampu untuk menjawab soal pada level 3. Namun siswa tidak mampu menjawab soal pada level 5 dan level 6, mungkin siswa juga tidak mampu untuk menjawab soal pada level 4.

3. Tinggi : Siswa pada kategori ini dinilai maSedangmpu untuk menjawab soal pada level 1 sampai dengan level 5, dan mungkin siswa juga mampu dalam menjawab soal pada level 6.

(Sumber: Take the Test: Sample Question from OECD's PISA Assessment 2009)

Deskripsi enam tingkat kemampuan dalam sains:

1. Level 6, siswa secara konsisten dapat mengidentifikasi, menjelaskan dan menerapkan pengetahuan ilmiah dan pengetahuan tentang sains dalam berbagai situasi kehidupan yang kompleks. Siswa dapat menghubungkan sumber informasi yang berbeda, penjelasan, dan menggunakan bukti dari berbagai sumber untuk menarik kesimpulan. Siswa jelas dan konsisten menunjukkan pemikiran ilmiah yang maju dan mempunyai penalaran, dan siswa dapat menggunakan pemahaman ilmiah dalam mendukung solusi untuk situasi ilmiah dan teknologi asing. Siswa pada tingkat ini dapat menggunakan pengetahuan ilmiah dan mengembangkan argumen untuk mendukung rekomendasi dan kesimpulan yang berpusat pada situasi pribadi, sosial atau global.

2. Level 5, siswa dapat mengidentifikasi komponen ilmiah dari banyak situasi kehidupan yang kompleks, menerapkan kedua konsep ilmiah dan pengetahuan tentang sains untuk situasi ini, dan dapat membandingkan, memilih dan mengevaluasi bukti ilmiah yang tepat untuk menanggapi situasi kehidupan. Siswa pada tingkat ini dapat menggunakan kemampuan inquiry yang telah berkembang dengan baik, pengetahuan link yang tepat dan membawa wawasan penting untuk situasi. Siswa dapat membangun penjelasan berdasarkan bukti dan argumen berdasarkan analisis kritis mereka.

3. Level 4, siswa dapat bekerja secara efektif dengan situasi dan masalah yang mungkin melibatkan fenomena eksplisit yang mengharuskan mereka untuk membuat kesimpulan tentang peran sains atau teknologi. Siswa dapat memilih dan mengintegrasikan penjelasan dari berbagai konsep sains dari ilmu pengetahuan atau teknologi dan menghubungkan penjelasannya langsung ke aspek situasi kehidupan. 
Siswa pada tingkat ini dapat merefleksikan tindakan dan dapat berkomunikasi tentang kesimpulan yang di hasilkan menggunakan pengetahuan ilmiah dan bukti-bukti ilmiah.

4. Level 3, siswa dapat mengidentifikasi dengan jelas, dan menjelaskan masalah ilmiah dalam berbagai konteks. Siswa dapat memilih fakta-fakta dan pengetahuan untuk menjelaskan fenomena dan menerapkan model sederhana atau strategi penyelidikan. Siswa pada tingkat ini dapat menafsirkan dan menggunakan konsep-konsep ilmiah dari berbagai konsep sains dan dapat menerapkannya secara langsung. Siswa dapat mengembangkan pernyataan singkat menggunakan fakta-fakta dan membuat kesimpulan berdasarkan pengetahuan ilmiah.

5. Level 2, siswa memiliki pengetahuan ilmiah yang memadai untuk memberikan penjelasan yang mungkin dalam konteks yang sudah diketahui atau menarik kesimpulan berdasarkan investigasi sederhana. Siswa mampu menggunakan penalaran langsung dan membuat interpretasi literal dari hasil penyelidikan ilmiah atau pemecahan masalah teknologi.

6. Level 1, siswa memiliki sebuah pengetahuan ilmiah yang terbatas yang hanya dapat diterapkan untuk beberapa, situasi yg sudah diketahui. Siswa dapat menyajikan penjelasan ilmiah yang jelas dan mengikuti secara eksplisit dari pemberikan buktibukti ilmiah.

(sumber: PISA 2009 framework e-book final)

\section{HASIL DAN PEMBAHASAN}

Penelitian ini dilaksanakan di SMP N I Tayu kabupaten Pati pada tanggal 16-23 Mei 2016. Penelitian ini bertujuan untuk mengetahui ada atau tidaknya pengaruh model discovery learning terhadap penguasaan literasi sains siswa pada mata pelajaran IPA terpadu. Model discovery learning diterapkan pada kelas eksperimen, sedangkan untuk kelas kontrol tanpa menggunakan model pembelajaran. Sebelum pembelajaran dimulai diadakan kegiatan pretest untuk mengetahui keampuan awal siswa baik di kelas kontrol maupun di kelas eksperimen. Setelah semua pertemuan dan pembelajaran selesai dilaksanakan maka diadakan kegiatan postest sebagai evaluasi untuk mengetahui pemahaman akhir tentang materi yang diberikan. Berdasarkan hasil penelitian yang telah dilakukan diperoleh data skor siswa dari hasil tes menggunakan soal-soal terjemahan sains PISA yang diberikan pada saat pretest dan postest, hasil angket literasi untuk mengungkap karakteristik siswa yang memiliki literasi sains, lembar observasi ketercapaian model pembelajaran discovery learning. Hasil penelitian tersebut akan memberikan gambaran tentang ada atau tidaknya pengaruh model discovery learning pada mata pelajaran IPA terpadu terhadap penguasaan literasi sains siswa.

Pada penelitian ini peniliti menggunakan soal-soal terjemahan sains PISA untuk mengetahui kemampuan literasi sains siswa. Dimana soal-soal terjemahan sains PISA yang diterbitkan oleh OECD pada tahun 2009 telah teruji melalui pengalaman tes dan uji coba dalam skala internasional. Soal-soal terjemahan PISA ini sudah divalidasi bahasa pada penelitian yang telah dilakukan sebelumnya oleh saudara Tiya Dwi Yuliastriani dalam penelitiannya yang berjudul "Menganalisis Kemampuan Siswa dalam Mengerjakan Soal PISA". Pada penelitian ini soal-soal terjemahan sains PISA yang digunakan adalah soal yang memiliki keterkaitan dengan materi pemanasan global sesuai dengan materi yang diberikan ketika pembelajaran.

Penelitian ini mengambil sampel siswa di SMP N I Tayu dengan memilih sampel yang bersumber dari dua kelas yaitu kelas VII E sebagai kelas kontrol dan kelas VII C sebagai kelas eksperimen. Soal pretest, postest, angket, dan lembar observasi ini diberikan pada kelas kontrol dan kelas eksperimen. Hasil penelitian yang telah dilakukan adalah sebagai berikut : 


\section{a. Hasil kemampuan siswa dalam menjawab soal-soal terjemahan PISA}

Sebelum melakukan penelitian, peneliti mengambil data awal siswa baik dari kelas kontrol maupun kelas eksperimen melaluai pretest untuk mengetahui apakah kedua kelas tersebut berawal dari kelas yang memiliki kemampuan sama atau tidak. Adapun hasil pretest dari masing-masing kelas adalah sebagai berikut :

Tabel 2. Hasil Pretest Kelas Kontrol dan Kelas Eksperimen

\begin{tabular}{|c|c|c|}
\hline Kelas & $\begin{array}{c}\text { Jumlah } \\
\text { Siswa }\end{array}$ & $\begin{array}{l}\text { Nilai rata- } \\
\text { rata }\end{array}$ \\
\hline Kontrol & 22 & 38 \\
\hline Eksperimen & 22 & 40 \\
\hline
\end{tabular}

Sumber : Analisis Hasil Penelitian(2016)

Hasil skor total siswa secara keseluruhan diperoleh rata-rata kelas sebesar 38 dengan rata-rata skor 9,8. Skor tertinggi sebesar 15 dengan perolehan nilai 58 dan skor terendah sebesar 6 dengan perolehan nilai 23 .

Tabel 3. Distribusi Frekuensi Nilai Pretest Kelas Kontrol

\begin{tabular}{cccc}
\hline No & Interval Nilai & Frekuensi & $\begin{array}{c}\text { Presentase Nilai } \\
\text { Siswa (\%) }\end{array}$ \\
\hline 1. & $23-28$ & 4 & $18,2 \%$ \\
2. & $29-35$ & 7 & $31,8 \%$ \\
3. & $36-41$ & 3 & $13,6 \%$ \\
4. & $42-47$ & 5 & $22,7 \%$ \\
5. & $48-53$ & 0 & $0 \%$ \\
6. & $54-59$ & 3 & $13,6 \%$ \\
\hline Jumlah & 22 & $100 \%$ \\
\hline Jumlah Nilai Siswa & & 831 \\
\hline Rata-Rata & & 38 \\
\hline Median & & 36,5 \\
\hline Modus & & 31,9 \\
\hline Simpangan baku & & 10.39 \\
\hline
\end{tabular}

Sumber : Analisis Hasil Penelitian (2016)

Hasil skor total siswa secara keseluruhan diperoleh rata-rata kelas sebesar 40 dengan rata-rata skor. Skor tertinggi sebesar 16 dengan perolehan nilai 62 dan skor terendah sebesar 4 dengan perolehan nilai 15 . 
Tabel 4. Distribusi Frekuensi Nilai Pretest Kelas Eksperimen

\begin{tabular}{cccc}
\hline No & Interval Nilai & Frekuensi & $\begin{array}{c}\text { Presentase Nilai } \\
\text { Siswa (\%) }\end{array}$ \\
\hline 1. & $15-22$ & 1 & $4,5 \%$ \\
2. & $23-30$ & 6 & $27,3 \%$ \\
3. & $31-38$ & 7 & $13,8 \%$ \\
4. & $39-46$ & 3 & $22,6 \%$ \\
5. & $47-54$ & 2 & $9.1 \%$ \\
6. & $55-62$ & 3 & $13,6 \%$ \\
\hline Jumlah & 22 & $100 \%$ \\
\hline Jumlah Nilai Siswa & & 846 \\
\hline Rata-Rata & & 40 \\
\hline Median & & 36,5 \\
\hline Modus & & 31,9 \\
\hline Simpangan baku & & 12.29 \\
\hline
\end{tabular}

Sumber : Analisis Hasil Penelitian (2016)

Setelah diberikan pretest, kedua kelas sampel ini diberikan pembelajaran dengan perlakuan yang berbeda. Kelas C sebagai kelas eksperimen diberikan pembelajaran dengan menggunakan model discovery learning, sedangkan kelas E sebagai kelas kontrol diberikan pembelajaran tanpa menggunkan model pembelajaran. Setelah diberikan pembelajaran dengan perlakuan yang berbeda, kedua kelas sampel tersebut diberi postest untuk mengetahui hasil akhir pembelajran siswa selain itu postest ini untuk mengetahui ada tidaknya pengaruh model discovery learning terhadap penguasaan literasi sains siswa pada mata pelajaran IPA terpadu. Hasil nilai postest di kelas kontrol dan kelas eksperimen, dimana kelas kontrol memiliki rata-rata nilai 60 sedangkan kelas eksperimen memiliki nilai rata-rata 62 .

\section{b. Hasil tingkat kemampuan siswa pada setiap level soal-soal terjemahan sains PISA}

Tabel 5. Tingkat kemampuan siswa pada setiap level soal-soal terjemahan sains PISA (Pretest kelas kontrol)

\begin{tabular}{cccc}
\hline No. & Level PISA & Persentase Skor Rata-rata & Kriteria \\
\hline 1 & 1 & $29,5 \%$ & Sangat Kurang \\
\hline 2 & 2 & $38,64 \%$ & Sangat Kurang \\
\hline 3 & 3 & $59,09 \%$ & Sangat Kurang \\
\hline 4 & 4 & $61,36 \%$ & Cukup \\
\hline 5 & 5 & $26,14 \%$ & Sangat Kurang \\
\hline 6 & 6 & $34,52 \%$ & Sangat Kurang \\
\hline
\end{tabular}

Sumber : Analisis Hasil Penelitian (2016)

Berdasarkan tabel di atas, level 4 memiliki presentase skor rata-rata lebih tinggi dibandingkan yang lain dan masuk pada kategori "cukup". Berdasarkan pengamatan, hal ini terjadi karena pada level 4 memiliki jenis soal yang berupa pilihan ganda dan soal jawaban YA/TIDAK atau jawaban singkat. Kedua jenis soal tersebut memudahkan siswa 
untuk menganalisis dan memecahkan soal, sehingga memungkinkan siswa dapat memecahkan masalah dengan tepat.

Tabel 6. Tingkat kemampuan siswa pada setiap level soal-soal terjemahan sains PISA (Pretest kelas eksperimen)

\begin{tabular}{cccc}
\hline No. & Level PISA & Persentase Skor Rata-rata & Kriteria \\
\hline 1 & 1 & $39,1 \%$ & Sangat Kurang \\
\hline 2 & 2 & $50,0 \%$ & Sangat Kurang \\
\hline 3 & 3 & $43,5 \%$ & Sangat Kurang \\
\hline 4 & 4 & $48,9 \%$ & Sangat Kurang \\
\hline 5 & 5 & $26,1 \%$ & Sangat Kurang \\
\hline 6 & 6 & $23,9 \%$ & Sangat Kurang \\
\hline
\end{tabular}

Sama halnya dengan hasil pretest kelas kontrol, pada hasil pretest kelss ekperimen level 4 mencapai skor yang lebih tinggi dibandingkan dengan level yang lain, akan tetapi perolehan presentasenya lebih kecil yaitu $48,9 \%$ dan termasuk dalam kriteria sangat kurang.

Untuk mengetahui hasil akhir dari penelitian dilakukan posttest pada kedua kelas sampel. Beriku ini adalah hasil posttest dari kelas kontrol dan kelas eksperimen :

Tabel 7. Tingkat kemampuan siswa pada setiap level soal-soal terjemahan sains PISA (Postest kelas kontrol)

\begin{tabular}{cccc}
\hline No. & $\begin{array}{c}\text { Level } \\
\text { PISA }\end{array}$ & $\begin{array}{c}\text { Persentase Skor } \\
\text { Rata-rata }\end{array}$ & Kriteria \\
\hline 1 & 1 & $29,5 \%$ & Sangat Kurang \\
\hline 2 & 2 & $38,64 \%$ & Sangat Kurang \\
\hline 3 & 3 & $59,09 \%$ & Sangat Kurang \\
\hline 4 & 4 & $61,36 \%$ & Cukup \\
\hline 5 & 5 & $26,14 \%$ & Sangat Kurang \\
\hline 6 & 6 & $34,52 \%$ & Sangat Kurang \\
\hline
\end{tabular}

Sumber : Analisis Hasil Penelitian (2016)

Berdasarkan tabel di atas, hasil posttest kelas kontrol menunjukkan level 4 dan level 2 mencapi peringkat tertinggi. Pada level 2 presentase skor rata-rata adalah 80,7\% sedangkan pada level 4 presentase skor rata-rata adalah $85,2 \%$.

Hasil posttest kelas eksperimen menunjukkan hasil yang hampir sama dengan kelas kontrol, dimana skor tertinggi dicaai pada level 2 dan 4. Dengan presentase skor rata-rata pada level 2 mencapai 72,2\% sedangakan pada level 4 mencapai skor 63,6\%.

Tabel 8. Tingkat kemampuan siswa pada setiap level soal-soal terjemahan sains PISA (Postest kelas eksperimen) 


\begin{tabular}{cccc}
\hline No. & $\begin{array}{c}\text { Level } \\
\text { PISA }\end{array}$ & $\begin{array}{c}\text { Persentase Skor } \\
\text { Rata-rata }\end{array}$ & Kriteria \\
\hline 1 & 1 & $39,1 \%$ & Sangat Kurang \\
\hline 2 & 2 & $50,0 \%$ & Sangat Kurang \\
\hline 3 & 3 & $43,5 \%$ & Sangat Kurang \\
\hline 4 & 4 & $48,9 \%$ & Sangat Kurang \\
\hline 5 & 5 & $26,1 \%$ & Sangat Kurang \\
\hline 6 & 6 & $23,9 \%$ & Sangat Kurang \\
\hline
\end{tabular}

Sumber : Analisis Hasil Penelitian (2016)

Berdasarkan tabel di atas ada tiga jenis kriteria pada hasil posttest kelas ekperimen yaitu level 1, 5 dan 6 termasuk dalam kriteria "Sangat kurang", level 2 dan 4 mencapai kriteria "Baik", dan level 3 mencapai kriteria "Cukup".

\section{c. Hasil Angket (kuesioner)}

Kuesioner dalam penelitian ini bertujuan untuk mengungkapkan karakteristik individu yang memiliki kemampuan literasi sains. Instrument kuesioner yang digunakan peneliti untuk mengetahui karakteristik siswa SMP N I Tayu berkenaan dengan literasi sains siswa mengacu pada National Science Teacher Association (NSTA) (Toharudin, 2011).

Tabel 9. Hasil pengisian kuesioner kelas kontrol

\begin{tabular}{cccc}
\hline No & Interval Nilai & Frekuensi & $\begin{array}{c}\text { Presentase Nilai } \\
\text { Siswa ( } \%)\end{array}$ \\
\hline 1. & $58-64$ & 1 & $4,5 \%$ \\
2. & $65-71$ & 5 & $22,7 \%$ \\
3. & $72-78$ & 7 & $31,8 \%$ \\
4. & $79-85$ & 4 & $18,2 \%$ \\
5. & $86-92$ & 4 & $18,2 \%$ \\
6. & $93-99$ & 1 & $4,5 \%$ \\
& & & $100 \%$ \\
\hline Jumlah & 22 & 1688 \\
\hline Jumlah Nilai Siswa & & 77 \\
\hline \multicolumn{2}{l}{ Rata-Rata } \\
\hline
\end{tabular}

Sumber : Analisis Hasil Penelitian (2016)

Hasil kuseioner dari 22 siswa di kelas kontrol menunjukkan nilai rata-rata sebesar 77. Dimana 7 dari 22 siswa berada pada interval nilai 72-78. 
Tabel 8. Hasil pengisian kuesioner kelas eksperimen

\begin{tabular}{cccc}
\hline No & Interval Nilai & Frekuensi & $\begin{array}{c}\text { Presentase Nilai } \\
\text { Siswa (\%) }\end{array}$ \\
\hline 1. & $53-59$ & 1 & $4,5 \%$ \\
2. & $60-66$ & 1 & $4,5 \%$ \\
3. & $67-73$ & 9 & $13,6 \%$ \\
4. & $74-80$ & 5 & $13,6 \%$ \\
5. & $81-87$ & 4 & $40.9 \%$ \\
6. & $88-94$ & 2 & $27,3 \%$ \\
\hline Jumlah & 22 & $100 \%$ \\
\hline Jumlah Nilai Siswa & & 1646 \\
\hline \multicolumn{2}{l}{ Rata-Rata } \\
\hline \multicolumn{2}{l}{ Sumber : Analisis Hasil Penelitian (2016) } \\
\end{tabular}

Tabel 7 dan 8 menunjukkan nilai rata-rata kelas kontrol adalah 77 dengan nilai tertinggi 95, sedangkan nilai rata-rata kelas eksperimen adalah 75 dengan skor tertinggi 90.

Berdasarkan hasil observasi yang dilakukan oleh observer, 91,3\% pembelajaran dengan menerapkan model discovery learning terlaksanaan sesuai dengan sintaks model discovery learning. Dalam menerapkan model pembelajaran ini ada bebrapa kendala yang ditemui yaitu waktu yang kurang memadai serta fasilitas pembelejaran.

Rendahnya perolehan skor siswa SMP N 1 Tayu diantaranya disebabkan oleh siswa yang belum terbiasa mengerjakan soal sejenis soal PISA yang memuat bahan bacaan yang panjang dan penggunaan bahasa ilmiah, sehingga butuh waktu yang lama untuk menganalisis, memahami serta memecahkan soal PISA. Faktor lain yang menyebabkan rendahnya skor siswa dalam mengerjakan soal-soal PISA adalah kurangnya pengetahuan siswa dan guru tentang soal-soal PISA.

Pada tahap awal pengenalan literasi sains dan soal-soal PISA, siswa membutuhkan bimbingn dan tuntunan dari guru secara inensf, sedangkan pada penelitian ini digunakan model pembelajaran discovery learning dimana siswa dituntut untuk belajar menemukan dan meyelidiki permasalahan yang ditemukan secara mandiri.Dimana dalam pembelajaran yang menerapkan model discovery learning ini siswa diharapkana memiliki kemampuan berpikir rasional yang memadai, sedangkan subjek penelitian adalah siswa kelas VII SMP yang masih memiliki kemampuan berpikir rasional yang masih terbatas. Ha ini yang menyebabkan siswa mendapatkan nilai yang rendah dalam mengerjakan soalsoal PISA pada penelitian ini.

\section{SIMPULAN}

Berdasarkan hasil penelitian dan pembahasan yang telah dilakukan dapat disimpulkan bahwa penerapan model pembelajaran discovery learning tidak memiliki pengaruh terhadap upaya peningkatan penguasaan literasi sains siswa dalam mata pelajaran IPA terpadu. Hasil penelitian menunjukkan kelas eksperimen yang di beri perlakukan dengan menggunakan model discovery learning pada proses pembelajaran ternyata mencapai skor rata-rata yang hampir sama dengan kelas kontrol, dimana pada kelas kontrol tidak diberi perlakuan dalam 
proses pembelajarannya. Bahkan pada beberapa level, yaitu level 2,3, dan level 4 kelas kontrol memiliki skor rata-rata yang lebih tinggi dibandingkan kelas eksperimen.

Pencapaian skor yang kurang maksimal oleh siswa SMP N 1 Tayu dalam mengerjakan soal PISA disebabkan karena intensitas pemberian pembelajaran serta latihan soal-soal yang memiliki karakteristik yang setara dengan soal PISA masih kurang, sehingga siswa belum terlatih dalam menyelesaikan soal-soal yang sesuai dengan PISA. Siswa SMP N 1 Tayu masih dalam tahapan awal dalam mengenal dan mengerjakan soal-soal PISA. Upaya melatih siswa dalam mengerjakan soal PISA ini pada tahapan pengenalan yaitu dengan memberi banyak pengarahan kepada siswa, hal ini tidak sesuai dengan model pembelajaran discovery dimana siswa dituntut secara mandiri menemukan permasalahan dan penyelesaian masalah, oleh karena itu model discovery learning tidak tepat apabila diterapkan untuk membantu meningkatkan kemampuan literasi sains siswa pada tahap awal atau pengenalan.

\section{REKOMENDASI}

Berdasarkan hasil penelitian dan pembahasan maka saran yang dapat peneliti sampaikan dalam upaya meningkatkan penguasaan literasi sains siswa yaitu :

1. Guru perlu meningkatkan intensitas pemberian latihan soal yang setipe dengan soal PISA secara intensif dalam pembelajaran, karena dengan soal tersebut dapat membantu siswa untuk berpikir tingkat tinggi.

2. Pada tahap awal pengenalan literasi sains dan soal PISA, model pembelajaran contextual lebih tepat untuk digunakan, karena pada tahapan ini siswa membutuhkan bimbingan dan tuntunan guru secara intensif sehingga siswa mampu pemahaman konsep soal PISA secara maksimal.

3. Penerapan model Discovery Learning akan lebih maksimal jika digunakan oleh siswa yang sudah menguasai konsep materi pembelajaran serta sudah sering berlatih mengerjakan soal-soal yang setipe dengan soal PISA. Hal ini dikarenakan pada model Discovery Learning siswa diharapkan dapat menemukan serta menyelidiki permasalahan secara mandiri, sehingga model ini kurang sesuai jika diterapkan pada tahap awal pengenalan literasi sains dan soal PISA.

\section{DAFTAR PUSTAKA}

Bagiarta, Nyoman. 2015. "Komparasi Literasi Sains antara Siswa yang Dibelajarkan dengan Model Pembelajaran Kooperatif Tipe GI (Group Investigation) dan Model Pembelajaran Inquiry Terbimbing (Guided Inquiry )Ditinjau dari Motivasi Berprestasi Siswa SMP". e-Journal Program PascaSarjana Universita Pendidikan Ganesha. 3.

Djamarah, Bahari. 2010. Strategi Belajar Mengajar. Jakarta: Rineka Cipta.

Ekohariadi. 2009. "Faktor-faktor yang mempengaruhi Literasi sains siswa Indonesia berusia 15 tahun". Jurnal pendidikan dasar.

Hendriani. 2008. "Pengaruh Pembelajaran IPA Terpadu terhadap Pengembangan Literasi Sains Siswa SMPN 3 Cimahi dan SMPN I Lembang". 5.

Illahi, Muhammad. 2012. Pembelajran Discovery Strategy dan Mental Vocational Skill. Jogjakarta: Diva Press.

Nyoman, Bagiarta. 2015. "Komparasi Literasi Sains dengan Model Kooperatif Tipe GI (Group Investigation) dan Model Pembelajaran Inkuiri Terbimbing (Guided Inquiry) Ditijnau dari Motivasi Belajar Siswa SMP". e-journal Program Pascasarjana 


\section{Universitas Pendidikan Ganesha.2.}

Widiadyana. 2014. "Pengaruh Discovery Learning terhadap Peahaman Konsep IPA dan Sikap Ilmiah Siswa SMP". e-journal Pascasarjana Universitas Pendidikan Ganesha. 